\title{
Pengaruh Kebijakan Dividen Dan Kebijakan Pendanaan Terhadap Harga Saham Melalui Kesempatan Investasi Dan Struktur Kepemilikan Saham Pada Perusahaan Industri Food And Beverage Yang Go Public Di Bursa Efek Indonesia
}

\author{
Nur Vita Opu, SE. MM \\ Jurusan Tata Boga \\ Politeknik Negeri Balikpapan \\ Jalan Soekarno Hatta KM. 8 \\ Email : nur.vita@poltekba.ac.id
}

\begin{abstract}
The development of capital market in Indonesia since 1988 show that the number has been increased. This development is very useful for companies and corporate investors. This study aimed to examine the effect of dividend policy and funding policy for investment opportunities, ownership structure, implementing to stock prices. The object of this research is a food and beverage company listed on the Indonesia Stock Exchange (BEI), year 2009 until 2012. There are 20 companies were selected as the study sample. Analysis tool used is the Path Analysis with exogenous variables are dividend policy and funding policy, and endogenous variables are investment opportunities, ownership structure, and stock prices.

The Aims of this research are determine Influence of Dividend Policy and Funding Policy to Stock Price with Mediation Investment Opportunities and Ownership Structure. Results of path analysis showed that the dividend policy and funding policies affect the ownership structure, and does not affect the investment opportunity. On the other hand, dividend policy, funding policy and ownership structure affect the stock price. Advice for companies in order to increase the funding policy and dividend policy. Because the two policies can increase the shareholding structure, as well as the improvement of the company's stock price. This will result in increased transparency to shareholders up to public thereby increasing investor confidence and rising stock prices or the value of the company as well as the increasing development of the Indonesian capital market.
\end{abstract}

Keywords: dividend policy, funding policy, investment opportunities, ownership structure, and stock prices

\begin{abstract}
Abstrak
Perkembangan pasar modal Indonesia sejak tahun 1988 menunjukkan jumlah yang mengalami peningkatan.Perkembangan ini sangat berguna bagi perusahaan investor maupun perusahaan.Penelitian ini bertujuan untuk menguji pengaruh kebijakan dividen dan kebijakan pendanaan terhadap kesempatan investasi, struktur kepemilikan saham, serta harga saham. Obyek penelitian adalah perusahaan food and beverage go publik yang terdaftar di Bursa Efek Indonesia (BEI), pada tahun 2009 hingga 2012. Terdapat 20 perusahaan yang terpilih sebagai sampel penelitian.Alat analisis yang digunakan adalah Analisis Path dengan variabel eksogen adalah kebijakan dividen dan kebijakan pendanaan, dan variabel endogen adalah kesempatan investasi, struktur kepemilikan saham, serta harga saham.

Tujuan dari penelitian ini adalah untuk mengetahui pengaruh deviden dan kebijakan pendanaan terhadap harga saham melalui kesempatan investasi dan struktur kepemilikan saham. Hasil analisis path memperlihatkan bahwa kebijakan dividen dan kebijakan pendanaan berpengaruh terhadap struktur kepemilikan saham, dan tidak berpengaruh terhadap kesempatan investasi. Di sisi lain, kebijakan dividen, kebijakan pendanaan serta struktur kepemilikan saham berpengaruh terhadap harga saham. Saran bagi perusahaan agar dapat meningkatkan kebijakan pendanaan maupun kebijakan dividen.Karena kedua kebijakan tersebut dapat meningkatkan struktur kepemilikan saham, serta perbaikan harga saham perusahan. Hal ini akan berdampak pada meningkatnya transparansi kepada pemegang saham terlebih publik sehingga meningkatkan kepercayaan investor dan naiknya harga saham atau nilai perusahaan serta meningkatnya perkembangan pasar modal Indonesia.
\end{abstract}

Kata kunci: Kebijakan Dividen, Kebijakan Pendanaan, Investasi, Kepemilikan Saham, Harga Saham. 


\section{Pendahuluan}

Perkembangan pasar modal Indonesia setelah tahun 1988 menunjukkan jumlah yang signifikan, bahkan pernah dikatakan bahwa pasar modal Indonesia merupakan bursa berkembang tercepat di dunia yang terlihat dari peningkatan jumlah emiten yang terus bertambah dalam waktu singkat dari tahun ke tahun. Hal itu ditunjang juga dengan pemberlakuan otomatisasi perdagangan pada tanggal 22 Mei 1995 silam.Adapun perkembangan bisnis dalam bentuk perdagangan saham di pasar modal menjadikan informasi mengenai kondisi perusahaan publik sangat berharga bagi para investor.

Peningkatan harga saham otomatis akan meningkatkan nilai perusahaan dan menarik investor, namun peningkatan tersebut tidak terlepas dari keputusan keuangan yang diambil oleh pihak pengelola perusahaan dalam hal ini manajemen perusahaan. Untuk mewujudkan hal tersebut, diperlukan kerjasama yang baik antara pihak manajemen perusahaan dengan pemegang saham maupun pihak lain seperti blockholder terkait pengambilan keputusan dalam menentukan kebijakan perusahaan. Apabila tindakan manajer dengan para pemegang saham dan pihak lainnya sejalan, maka hal yang merugikan perusahaan akan terhindar. Adapun struktur kepemilikan saham perusahaan merupakan distribusi kepemilikan saham suatu perusahaan yang terbagi antara pihak internal dalam hal ini kepemilikan manjerial, dan pihak eksternal dalam hal ini kepemilikan institusi dan publik.

\section{Metode Penelitian}

\subsection{Rancangan Penelitian}

Kerangka dalam penelitian ini menggunakan paradigma positif dengan pendekatan kuantitatif.Pendekatan penelitian ini menguji teori-teori dengan menggunakan angka-angka dan metode statistik dalam melakukan analisa data (Indriantoro dan
Supomo, 2002).Jenis penelitian ini adalah jenis penelitian eksplanatoris (explanatory).

\subsection{Definisi Operasional}

Untuk memberikan penjelasan mengenai indikator yang digunakan dalam penelitian dan usaha pemecahan masalah sesuai dengan judul penelitian ini, maka dirumuskan mengenai definisi operasional yang dapatdijabarkan sebagai berikut:

\section{1) Variabel Endogen yang terdiri dari}

a. $Y_{1}=$ Kesempatan Investasi

b. $Y_{2}=$ Struktur Kepemilikan Saham

c. $\mathrm{Y}_{3}=$ Harga Saham

2) Variabel Eksogen yang terdiri dari :

a. $\mathrm{X}_{1}=$ Kebijakan Dividen

b. $\mathrm{X}_{2}=$ Kebijakan Pendanaan

\subsection{Data Yang Diperlukan}

Data yang digunakan dalam penelitian ini adalah data yang telah dijelaskan pada subbab Definisi Operasional yang meliputi 5 variabel. Perincian data yang diperlukan dari tiap tiap perusahaan sampel yang merupakan perusahaan food and beverage go public yang terdaftar di Bursa Efek Indonesia (BEI) menurut pengklasifikasian Indonesian Capital Market Directory (ICMD) pada Laporan Keuangan Tahun 2009, 2010, 2011, dan 2012 yang meliputi Total Dividend, Total Saham, Total Hutang, Total Nilai Buku Ekuitas, Total Saham Manajerial, Total Saham Beredar, Total Aset, Total Ekuitas, Lembar Saham Beredar, Harga Penutupan Saham Akhir, danNilai Buku Perlembar Saham

\subsection{Populasi dan Sampel}

Populasi yang digunakan dalam penelitian ini adalah seluruh perusahaan food and beverage go public yang terdaftar di Bursa Efek Indonesia (BEI) menurut pengklasifikasian Indonesian Capital Market Directory (ICMD). Dari jumlah populasi akhir sebesar 171 perusahaan, yang memenuhi persayaratan sebanyak 20 Perusahaan, Waktu pengamatan sebanyak 4 tahun (2009 hingga 2012), sehingga total sampel sebanyak 80 sampel.

\subsection{Sumber Data}

Data dalam penelitian ini adalah berupa data sekunder dari laporan keuangan tahunan 
perusahaan. Pengumpulan data menggunakan teknik dokumentasi yang diperoleh dari database Bursa Efek Indonesia yang tersedia dalam Indonesian Capital Market directory (ICMD) dari tahun 2009-2012.

\section{Instrumen Penelitian}

Berkaitan dengan data yang digunakan adalah data sekunder, maka tidak diperlukan pembuatan instrumen penelitian seperti pada data primer.Jadi instrumen yang digunakan adalah langsung diperoleh dari hasil pengukuran dari database Bursa Efek Indonesia yang tersedia dalam Indonesian Capital Market directory (ICMD) dari tahun 2009-2012.

\subsection{Teknik Pengumpulan Data}

Data dalam penelitian ini adalah berupa data sekunder dari laporan keuangan tahunan perusahaan. Pengumpulan data menggunakan teknik dokumentasi yang diperoleh dari database Bursa Efek Indonesia yang tersedia dalam Indonesian Capital Market directory (ICMD) dari tahun 20092012.

\subsection{Analisis Data}

Alat analisis yang digunakan menggunakan kerangka pathanalysis berkisar pada : pertama, apakah variable eksogen $\left(\mathrm{X}_{1}\right.$, $\left.\mathrm{X}_{2}, \ldots, \mathrm{X}_{\mathrm{n}}\right)$ berpengaruh signifikan terhadap variable endogen Y. Kedua berapa besar pengaruh kausal langsung, kausal tidak langsung, kausal total maupun simultan seperangkat varibel eksogen $\left(X_{1}, X_{2}, \ldots, X_{n}\right)$ terhadap variable endogen Y.

\section{Pengujian Asumsi Klasik}

a. Uji Normalitas

Uji normalitas diperlukan untuk mengetahui apakah error dari model regresi berdistribusi normal atau tidak.Error dari model regresi yang terbentuk harus memenuhi asumsi normalitas ini.Jika error model regresi tidak berdistribusi secara normal, maka statistic uji, apakah itu uji-t maupun uji $-\mathrm{F}$ tidak bisa diterapkan.Model regresi yang baik adalah memiliki distribusi normal atau mendekati normal. Salah satu cara untuk mendeteksi apakah error model regresi berdistribusi atau tidak adalah dengan memperhatikan probability plot residual. Jika probability plot residual berada disekitar garis horizontal, maka error dari model tersebut dikatakan berdistribusi secara normal.

b. Uji Heteroskedastisitas

Uji ini bertujuan untuk menguji apakah dalam model regresi terjadi ketidaksamaan variance dari residual satu pengamatan ke pengamatan yang lain. Jika variance dari satu residual satu pengamatan ke pengamatan lain tetap, maka disebut homoskedastisitas dan jika berbeda disebut heteroskedastisitas. Model regresi yang baik adalah yang homoskedastisitas dan tidak terjadi heteroskedastisitas (Ghozali,2009:35). Untuk mendeteksi adanya heteroskedastisitas dilakukan dengan melihat grafik plot antara nilai prediksi variabel terikat (ZPRED) dengan residualnya (SRESID). Jika ada pola tertentu, seperti titik-titik yang membentuk suatu pola tertentu yang teratur (bergelombang, melebar atau menyempit), maka mengindikasikan telah terjadi heteroskedastisitas.

\section{Hasil Dan Pembahasan Analisis Deskriptif}

Kebijakan Dividen (X1) secara keseluruhan selama 4 tahun pengamatan adalah sebesar 0.00000112739 .

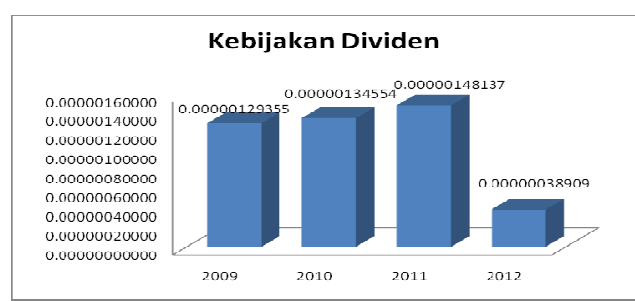

Gambar 1 Nilai rata-rata Kebijakan Dividen (X1)

Secara grafik, rata-rata nilai Kebijakan Dividen (X1) tiap tahun disajikan pada Gambar 1. Berdasarkan rata-rata tiap tahun, terlihat bahwa nilai Kebijakan Dividen (X1) tertinggi ada pada tahun 2011 yaitu sebesar 0.00000148137, dan nilai Kebijakan Dividen 
(X1) terendah pada tahun 2012 yaitu sebesar 0.00000038909 .

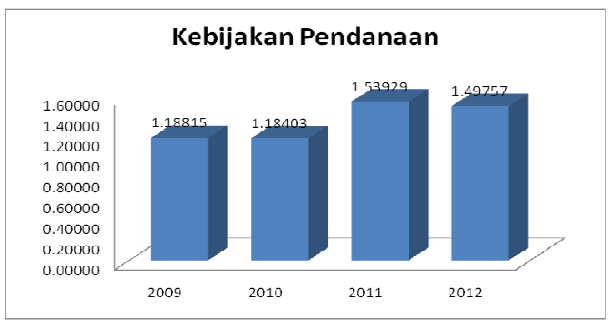

\section{Gambar 2 Nilai rata-rata Kebijakan}

Pendanaan

Secara grafik, rata-rata nilai Kebijakan Pendanaan tiap tahun disajikan pada Gambar 2. Berdasarkan rata-rata tiap tahun, terlihat bahwa nilai Kebijakan Pendanaan tertinggi ada pada tahun 2011 yaitu sebesar 1.53929, dan nilai Kebijakan Pendanaan terendah pada tahun 2010 yaitu sebesar 1.18403 .

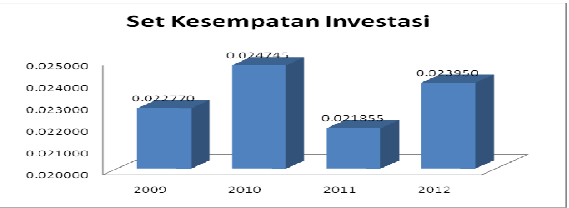

Gambar 3 Nilai rata-rata Kesempatan Investasi

Secara grafik, rata-rata nilai kesempatan Investasi tiap tahun disajikan pada Gambar 3. Berdasarkan rata-rata tiap tahun, terlihat bahwa nilai kesempatan Investasi tertinggi ada pada tahun 2010 yaitu sebesar 0.02475, dan nilai kesempatan Investasi terendah pada tahun 2011 yaitu sebesar 0.021855 .

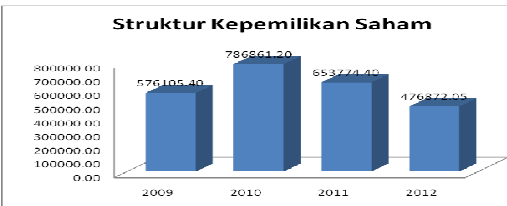

\section{Gambar 4 Nilai rata-rata Struktur Kepemilikan Saham}

Secara grafik, rata-rata Struktur Kepemilikan Saham tiap tahun disajikan pada Gambar 4. Berdasarkan rata-rata tiap tahun, terlihat bahwa nilai Struktur Kepemilikan Saham tertinggi ada pada tahun 2010 yaitu sebesar 786861.20, dan nilai Struktur
Kepemilikan Saham terendah pada tahun 2012 yaitu sebesar 476872.05.

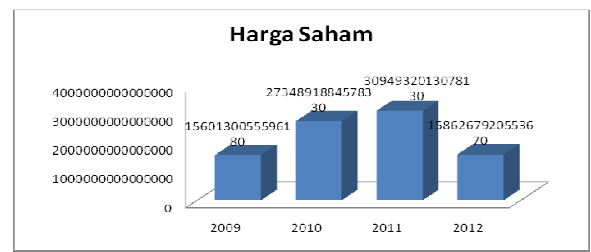

\section{Gambar 5 Nilai rata-rata Harga Saham}

Secara grafik, rata-rata nilai Harga Saham tiap tahun disajikan pada Gambar 5. Berdasarkan rata-rata tiap tahun, terlihat bahwa nilai Harga Saham tertinggi ada pada tahun 2011 yaitu sebesar 3094932013078130, dan nilai Harga Saham terendah pada tahun 2009 yaitu sebesar 1560130055596180 .

\section{Pengujian Asumsi Klasik \\ 1.Uji Normalitas}

Asumsi normalitas dilakukan dengan pengujian Kolmogorov-Smirnov, bila probabilitas hasil korelasi lebih besar dari 0.05 (5\%), maka asumsi normalitas terpenuhi.Hasil pengujian normalitas pada model pertama, kedua, dan ketigadiperoleh nilai probabilitas sebesar $0.614 ; 0.825$; dan 0.444 .Karena nilai probabilitas di atas $5 \%$, maka disimpulkan bahwa asumsi normalitas untuk analisis path ketiga persamaan terpenuhi.

\section{Homogenitas}

Asumsi homogenitas diuji dengan Uji Gletzer.Jika nilai Signifikansi variabel bebas di atas 0.5, maka asumsi tidak terjadinya heteroskedastisitas terpenuhi. Hasil perhitungan memperlihatkan nilai Sig pada model pertama antara $0.739-0.883$ $>0.05$;nilai Sig pada model kedua antara $0.863-0.923>0.05$; dan nilai Sig pada mdel ketiga antara $0.459-0.574>0.05$, sehingga asumsi homogenitas pada analisis path ketiga persamaan 


\section{Analisis Path Keseluruhan}

Dari ketiga persamaan analisis path pada subbab berikutnya diperoleh gambaran hasil analisis path secara keseluruhan sebagai berikut (garis merah menyatakan hubungan yang tidak signifikan, garis hitam menyatakan hubungan yang signifikan):

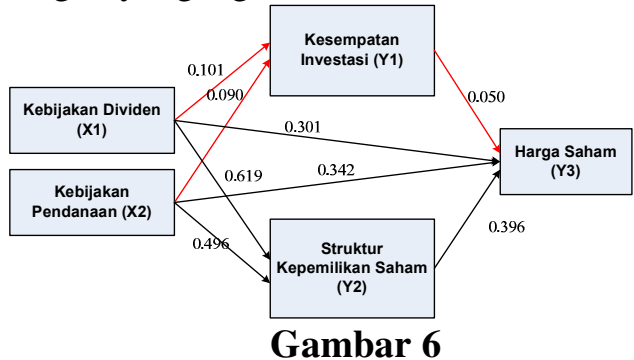

Hasil Analisis Path Keseluruhan

Pembahasan Hasil Penelitian

\section{Kebijakan Dividen \\ terhadap}

\section{Kesempatan Investasi}

Berdasarkan hasil analisis path terlihat bahwa Kebijakan Dividen tidak berpengaruh signifikan langsung terhadap Set Kesempatan Investasi.Artinya hipotesis yang menyatakan terdapat pengaruh antara Kebijakan Dividen terhadap Set Kesempatan Investasi ditolak.Sehingga tinggi rendahnya nilai Kebijakan Dividen (X1) tidak mempengaruhi tinggi rendahnya nilai Set Kesempatan Invastasi (Y1).

Penelitian ini juga tidak sejalan dengan temuan Belkaoui dan Picur (2001) yang menemukan variabel dividend yield dan price earnings ratio berpengaruh signifikan terhadap set kesempatan investasi yang terlihat pada relevansi atau kaitan nilai dividendyield dan price earnings ratio untuk perusahaan yang memiliki level kesempatan investasi tinggi dan rendah dimana price earnings ratio memiliki relevansi nilai yang lebih besar dibanding dividend yield pada perusahaan dengan set kesempatan investasi tinggi sedangkan pada perusahaan dengan set kesempatan investasi rendah, dividend yield memiliki relevansi nilai yang lebih besar dibanding price earnings ratio. Berikut disajikan grafik hubungan antara kebijakan dividen dengan kesempatan investasi.

\section{Kebijakan Dividen terhadap Struktur Kepemilikan Saham}

Berdasarkan hasil analisis path terlihat bahwa Kebijakan Dividen berpengaruh signifikan langsung terhadap Struktur Kepemilikan Saham.Artinya hipotesis yang menyatakan terdapat pengaruh antara Kebijakan Dividen terhadap Struktur Kepemilikan Saham diterima.Semakin tinggi nilai Kebijakan Dividen (X1), semakin tinggi pula nilai Struktur Kepemilikan Saham (Y2).

Hasil penelitian di atas
memperlihatkan bahwa struktur kepemilikan saham dipengaruhi oleh kebijakan dividen. Sebesar $64.2 \%$ struktur kepemilikan saham ditentukan oleh kebijakan dividen maupun kebijakan pendanaan. Dari besarnya koefisien path memperlihatkan bahwa kebijakan dividen (koefisien 0.619) lebih besar pengaruhnya terhadap struktur kepemilikan saham, dibandingkan pengaruhnya kebijakan pendanaan (koefisien path 0.496) terhadap struktur kepemilikan saham. Hal ini mengindikasikan bahwa struktur kepemilikan saham semakin baik, utamanya karena semakin baiknya kebijakan dividen.

Hasil penelitian ini sejalan dengan hasil penelitian Smith dan Watts (1992) bahwa pertumbuhan suatu perusahaan akan mempengaruhi sejumlah kebijakan oleh perusahaan. Kebijakan dividen menentukan struktur modal juga ditemukan oleh Risanty (2004). Di sisi lain, temuan ini juga menguatkan hasil temuan Pujiati dan Widanar (2006) bahwa struktur kepemilikan saham ditentukan oleh kebijakan dividen.

\section{Kebijakan Dividen terhadap Harga Saham}

Berdasarkan hasil analisis path terlihat bahwa Kebijakan Dividen berpengaruh signifikan langsung terhadap Harga Saham.Artinya hipotesis yang menyatakan terdapat pengaruh antara Kebijakan Dividen terhadap Harga Saham diterima.Semakin tinggi nilai Kebijakan Dividen (X1), semakin tinggi pula nilai Harga Saham (Y3).

Pengaruh tidak langsung antara Kebijakan Dividen (X1) terhadap Harga 
Saham (Y3) melalui Struktur Kepemilikan Saham (Y2), dengan koefisien pengaruh tidak langsung sebesar 0.2451 diperoleh dari perkalian antara pengaruh langsung variabel Kebijakan Dividen (X1) terhadap Struktur Kepemilikan Saham (Y2) dan pengaruh langsung antara variabel Struktur Kepemilikan Saham (Y2) terhadap Harga Saham (Y3). Karena pengaruh langsung (Kebijakan Dividen ke Struktur Kepemilikan Saham, dan Struktur Kepemilikan Saham ke Harga Saham) keduanya signifikan, maka dapat disimpulkan terdapat pengaruh tidak langsung yang signifikan antara Kebijakan Dividen terhadap Harga Saham melalui Struktur Kepemilikan Saham.Artinya semakin tinggi nilai Kebijakan Dividen, semakin tinggi pula nilai Harga Saham, jika nilai Struktur Kepemilikan Saham juga tinggi.

Hasil penelitian di atas memperlihatkan bahwa harga saham dipengaruhi oleh kebijakan dividen. Sebesar $67.0 \%$ harga saham ditentukan oleh kebijakan dividen maupun kebijakan pendanaan, serta struktur kepemilikan saham. Dari besarnya koefisien path memperlihatkan bahwa harga saham (koefisien 0396) lebih besar pengaruhnya terhadap struktur kepemilikan saham, dibandingkan pengaruhnya kebijakan pendanaan (koefisien path 0.342) serta kebijakan dividen (0.301) terhadap harga saham. Hal ini mengindikasikan bahwa harga saham semakin baik, utamanya karena semakin baiknya struktur kepemilikan saham.

Hasil penelitian ini sejalan dengan hasil penelitian Belkaoui dan Picur (2001) menemukan variabel dividend yield dan price earnings ratio berpengaruh signifikan terhadap harga saham. Penelitian ini sejalan dengan temuan Subekti dan Imam (2001) yang menguji pengaruh Dividen Perusahaan, pengaruhnya terhadap Perubahan Harga Saham. Rasio MVE/BVE, MVA/BVA dan CAP/BVA menunjukkan arah korelasi positif yang konsisten terhadap pertumbuhan perusahaan.

\section{Kebijakan Pendanaan terhadap Kesempatan Investasi}

Berdasarkan hasil analisis path terlihat bahwa Kebijakan Pendanaan tidak berpengaruh signifikan langsung terhadap Set Kesempatan Investasi.Artinya hipotesis yang menyatakan terdapat pengaruh antara Kebijakan Pendanaan terhadap Set Kesempatan Investasi ditolak.Sehingga tinggi rendahnya nilai Kebijakan Dividen (X2) tidak mempengaruhi tinggi rendahnya nilai Set Kesempatan Invastasi (Y1).

Hasil di atas mencerminkan bahwa kesempatan investasi perusahaan di indonesia tidak ditentukan secara mutlak oleh kebijakan pendanaan. Hasil ini tidak sejalan dengan temuan Smith dan Watts (1992), di mana temuan penelitian ini belum menemukan bukti bahwa pada perusahaan yang tumbuh atau memiliki set kesempatan investasi tinggi cenderung untuk mengikuti kebijakan pendanaan yang lebih rendah, hal itu untuk menurunkan masalah masalah agensi yang berasosiasi dengan kebebasan aliran kas perusahaan.

\section{Kebijakan Pendanaan terhadap Struktur Kepemilikan Saham}

Berdasarkan hasil analisis path terlihat bahwa Kebijakan Pendanaan berpengaruh signifikan langsung terhadap Struktur Kepemilikan Saham.Artinya hipotesis yang menyatakan terdapat pengaruh antara Kebijakan Pendanaan terhadap Struktur Kepemilikan Saham diterima.Semakin tinggi nilai Kebijakan Pendanaan (X2), semakin tinggi pula nilai Struktur Kepemilikan Saham (Y2).

Hasil penelitian di atas memperlihatkan bahwa struktur kepemilikan saham dipengaruhi oleh kebijakan pendanaan. Sebesar $64.2 \%$ struktur kepemilikan saham ditentukan oleh kebijakan dividen maupun kebijakan pendanaan. Hasil penelitian ini sejalan dengan hasil penelitian Smith dan Watts (1992) bahwa pertumbuhan suatu perusahaan akan mempengaruhi sejumlah kebijakan oleh perusahaan. Temuan ini juga menguatkan hasil temuan Pujiati dan Widanar (2006) bahwa struktur kepemilikan saham ditentukan oleh keputusan pendanaan. Di sisi 
lain, temuan penelitian ini tidak sejalan dengan apa yang ditemukan oleh Diana dan Irianto (2008) bahwa kebijakan pendanaan tidak berpengaruh signifikan terhadap struktur kepemilikan saham.

Wibowo dan Erkaningrum (2002) menyatakan kebijakan pendanaan merupakan salah satu kebijakan perusahaan yang memanfaatkan sumber pendanaan eksternal untuk membiayai kegiatan operasional perusahaan. Keputusan pendanaan menyangkut penentuan kombinasi berbagai sumber dana yang terbagi atas pendanaan ekstern yakni menentukan proporsi antara hutang jangka panjang dan modal sendiri, yang terlihat pada debt to equity ratio perusahaan. Di sisi lain, menurut Diana dan Irianto (2008), kepemilikan saham manajerial merupakan kepemilikan saham yang dimiliki oleh pihak internal perusahaan baik manajer maupun dewan komisaris dan direksi perusahaan. Kepemilikan Institusional merupakan kepemilikan saham institusi yang bukan merupakan manajemen perusahaan berupa institusi perusahaan, lembaga keuangan, jasa asuransi.

\section{Kebijakan Pendanaan terhadap Harga Saham}

Berdasarkan hasil analisis path terlihat bahwa Kebijakan Pendanaan berpengaruh signifikan langsung terhadap Harga Saham.Artinya hipotesis yang menyatakan terdapat pengaruh antara Kebijakan Pendanaan terhadap Harga Saham diterima.Semakin tinggi nilai Kebijakan Pendanaan (X2), semakin tinggi pula nilai Harga Saham (Y2).

Pengaruh tidak langsung antara Kebijakan Pendanaan (X2) terhadap Harga Saham (Y3) melalui Struktur Kepemilikan Saham (Y2), dengan koefisien pengaruh tidak langsung sebesar 0.1964 diperoleh dari perkalian antara pengaruh langsung variabel Kebijakan Pendanaan (X2) terhadap Struktur Kepemilikan Saham (Y2) dan pengaruh langsung antara variabel Struktur Kepemilikan Saham (Y2) terhadap Harga Saham (Y3). Karena pengaruh langsung
(Kebijakan Pendanaan ke Struktur Kepemilikan Saham, dan Struktur Kepemilikan Saham ke Harga Saham) keduanya signifikan, maka dapat disimpulkan terdapat pengaruh tidak langsung yang signifikan antara Kebijakan Pendanaan terhadap Harga Saham melalui Struktur Kepemilikan Saham.Artinya semakin tinggi nilai Kebijakan Pendanaan, semakin tinggi pula nilai Harga Saham, jika nilai Struktur Kepemilikan Saham juga tinggi.

Hasil penelitian di atas memperlihatkan bahwa harga saham dipengaruhi oleh kebijakan pendanaan. Sebesar $67.0 \%$ harga saham ditentukan oleh kebijakan dividen maupun kebijakan pendanaan, serta struktur kepemilikan saham. Penelitian ini sejalan dengan temuan Subekti dan Imam (2001) yang menguji pengaruh Kebijakan Pendanaan implikasinya pada Perubahan Harga Saham. Rasio MVE/BVE, MVA/BVA dan CAP/BVA menunjukkan arah korelasi positif yang konsisten terhadap pertumbuhan perusahaan. Penelitian ini juga sejalan dengan penelitian Pujiati dan Widanar (2006) bahwa keputusan pendanaan berpengaruh signifikan terhadap nilai perusahaan yang dicerminkan oleh harga saham.

\section{Kesempatan Investasi terhadap Harga Saham}

Berdasarkan hasil analisis path terlihat bahwa Kesempatan Investasi tidak berpengaruh signifikan langsung terhadap Harga Saham.Artinya hipotesis yang menyatakan tidak terdapat pengaruh antara Set Kesempatan Investasi terhadap Harga Saham diterima.Sehingga tinggi rendahnya nilai Set Kesempatan Investasi (Y1) tidak mempengaruhi tinggi rendahnya nilai Harga Saham (Y3).

Hasil penelitian ini tidak sejalan dengan hasil penelitian Subekti dan Kusuma (2001) bahwa investment opportunity set berkaitan erat (asoiasi) dengan harga saham. Hal ini mengindikasikan bahwa seberapapun tinggi atau rendahnya Rasio MBA (Gaver and 
Gaver, 1993) tidak berpengaruh signifikan terhadap harga saham.

\section{Struktur Kepemilikan Saham terhadap Harga Saham}

Berdasarkan hasil analisis path terlihat bahwa Struktural Kepemilikan Saham berpengaruh signifikan langsung terhadap Harga Saham.Artinya hipotesis yang menyatakan terdapat pengaruh antara Struktural Kepemilikan Saham terhadap Harga Saham diterima.Semakin tinggi nilai Struktural Kepemilikan Saham (Y2), semakin tinggi pula nilai Harga Saham (Y3).

Hasil penelitian di atas memperlihatkan bahwa harga saham dipengaruhi oleh struktur kepemilikan saham. Sebesar $67.0 \%$ harga saham ditentukan oleh kebijakan dividen maupun kebijakan pendanaan, serta struktur kepemilikan saham.

Penelitian ini tidak sejalan dengan temuan Sudarma (2004), bahwa struktur kepemilikan saham berpengaruh signifikan signifikan negatif terhadap nilai perusahaan. Penelitian ini menemukan bahwa struktur kepemilikan saham berpengaruh signifikan positif terhadap nilai perusahaan yang diproksikan oleh harga saham. Penelitian ini sejalan dengan penelitian Pujiati dan Widanar (2006) bahwa struktur kepemilikan saham berpengaruh signifikan positif terhadap nilai perusahaan yang dicerminkan oleh harga saham.

Diana dan Irianto (2008), kepemilikan saham manajerial merupakan kepemilikan saham yang dimiliki oleh pihak internal perusahaan baik manajer maupun dewan komisaris dan direksi perusahaan.Kepemilikan Institusional merupakan kepemilikan saham institusi yang bukan merupakan manajemen perusahaan berupa institusi perusahaan, lembaga keuangan, jasa asuransi. Semakin tingginya struktur kepemilikan saham, juga akan mengakibatkan semakin tinggi pula harga saham perusahaan.

\section{Kesimpulan}

Berdasarkan hasil analisis dan pembahasan dari penelitian ini, maka dapat dikemukakan beberapa kesimpulan sebagai berikut:

1. Kebijakan Dividen tidak berpengaruh signifikan terhadap Kesempatan Investasi.

2. Kebijakan Dividen berpengaruh signifikan terhadap Struktur Kepemilikan Saham.

3. Kebijakan Dividen berpengaruh signifikan terhadap Harga Saham.

4. Kebijakan Pendanaan tidak berpengaruh signifikan terhadap kesempatan Investasi.

5. Kebijakan Pendanaan berpengaruh signifikan terhadap Struktur Kepemilikan Saham.

6. Kebijakan Pendanaan berpengaruh signifikan terhadap Harga Saham.

7. Kesempatan Investasi tidak berpengaruh signifikan terhadap Harga Saham.

8. Struktur Kepemilikan Saham berpengaruh signifikan terhadap Harga Saham.

\section{Daftar Pustaka}

Diana, D. N. A. dan Irianto, G. (2008). Pengaruh Kegiatan Manajerial, Kepemilikan Institusional dan Sebaran Kepemilikan Terhadap Kebijakan Hutang Perusahaan Ditinjau dari Teori Keagenan. Emisi, 1 (1) : 1 $-16$.

Ghozali, I. 2008. Model Persamaan Struktural : Konsep Aplikasi dengan Program AMOS 16.0. Badan Penerbit Universitas Diponegoro. Semarang.

Indriantoro, N., dan B. Supomo. 2002. Metodologi Penelitian Bisnis untuk Akuntansi dan Manajemen. Edisi Pertama. BPFE, Yogyakarta.

Mulyadi.(2006). Sistem Akuntansi. Jakarta: Penerbit Salemba Empat.

Risanty,(2012).Hubungan Investment Opportunity Set dengan Kebijakan Dividen dan Struktur Modal.Program pascasarjana Universitas Sumatera Utara, Medan. 